\title{
Analysis on the Characteristics of Democratic Politics Based on Ecological Perspective*
}

\author{
Mengzhen Sun \\ Jilin Agricultural University \\ Changchun, China 130118
}

\author{
Xin Li \\ Jilin Agricultural University \\ Changchun, China 130118
}

\begin{abstract}
As the links among various fields of human society continue to deepen, the ecological characteristics of political development become more and more obvious. And the ecological concept has infiltrated into the course of political development. As an important part of the political system, democratic politics has its own ecological characteristics. From the perspective of political ecology, it is mainly reflected in the systemic nature of democratic political construction, the adaptability in the development of democratic politics, and the sustainability of democratic political development.
\end{abstract}

Keywords—political ecology; democratic politics; characteristics

\section{INTRODUCTION}

Democratic politics has always been beautiful appeal of human society. Different forms of democratic institutions appearing in the historical development of human society have their own characteristics. However, as various fields of human society continue to blend in the process of development, they interact and learn from each other in practice. And the development of democratic politics gradually presents ecological characteristics. From the perspective of political ecology theory, any political system is a dynamic system with certain structure and function. And it realizes co-evolution in the interaction of internal elements and cooperation and communication with the external environment. As an important part of the political system, democratic politics also conforms to the law of political ecology. Based on the ecology, this paper analyzes the ecological characteristics of democratic politics and seeks the best way to achieve democratic politics. It is of great significance for realizing the effective development of democratic politics and promoting the progress of human society.

\section{The Systematic NATURE OF Democratic Politics}

The internal elements of the democratic political system are interrelated and mutually constrained, forming a complex political system. At the same time, many internal factors interact and influence with the external political environment. Also, it carries out material, energy and information exchange activities with the external social environment composed of economic and cultural factors. And then, the internal and external environment can be closely connected

*CLC number: D610.1 Document code A to form a complete political ecosystem.

\section{A. The Internal Environment of Democratic Politics Constitutes a System}

From the perspective of political ecology, the internal components of the democratic political system and its interdependence constitute the internal environment for the survival and development of democratic politics. This internal environment is mainly composed of clear democratic political values, advanced democratic political systems and extensive democratic political subjects. These three fundamental dimensions do not exist in isolation from each other. There are inherent logical relationships among them. By interconnecting and interacting influence, they form a complete democratic political system.

First of all, the mainstream democratic political value is the inner soul of the democratic political system, and also the core of the ideological culture of the democratic political subject in the process of political practice. The broad masses of the people who are the subjects of democratic politics can avoid going astray when losing the spiritual pillar by firmly grasping the value of mainstream democratic politics. Secondly, the democratic political system provides a strong institutional guarantee for the realization of the mainstream democratic political value, and it is also the way and guarantee for the democratic political subject to realize the political will. Finally, from the perspective of the democratic political subject, the masses of the people are the creators of history. The democratic political values and democratic political systems depend on the democratic political subjects. Without the people, the democratic political values and democratic political systems lose their real significance. At the same time, without the people, democratic political values and democratic political systems cannot achieve innovative development.

\section{B. The Mutual Restraint and Balance Between the Democratic Political System and the External Political Environment}

As a subsystem of the political system, democratic political construction has its own inner environment for survival. As a subsystem of the political system, it creates an interdependent ecological relationship with other parallel subsystems of the political system and even the entire political system. In turn, it constitutes an external political 
environment in which the democratic political construction system operates, including the nature of the state, political stability, and legalization and institutionalization of political life, and so on. The democratic political system and its external political environment are mutually constrained and balanced, constituting a complete organic political system.

Throughout the development of democratic politics, its internal system and the external political environment are mutually restrained and constrained. At the same time, it is balanced and adapted to its external political environment. First of all, the state system determines the subject of politics, and the political system demonstrates the nature of the state. At the same time, the development of a democratic political system can also promote the overall political system and optimize the development of the political system. Secondly, the stability of the national political system is closely related to the process and effect of democratic political construction. The national political system and the superior external political environment of democratic political construction are more stable. It will create favorable conditions for the development of democratic politics. Conversely, as an important part of the national political system, democratic politics can also promote the overall stability of national politics. Finally, the construction of democratic politics relies on the legalization and institutionalization of due process. The legalization and legalization of political life restrict the development of democratic political construction.

\section{The Democratic Political System and the Social System Realize Energy Transmission and Information Exchange}

The democratic political system does not exist in isolation. As a subsystem of the political system, it is closely related to the interaction and influence of its external political environment, and the economic, cultural and social construction beyond the political system on which it depends. This kind of correlation forms the social environment in which democratic politics is built. The democratic political system and social system carry out energy transmission and information exchange. Thereby, it would maximize the interaction between internal system and external environment.

First of all, "there is a kind of symbiotic relationship between democratic politics and commodity economy from the perspective of political ecology theory. The matching relationship between democratic politics and market economy is the most ecologically relevant relationship so far. The market economy is a democratic economy with institutional genes that induce democratic politics." [1] The economic democracy and self-owned attributes of the market economy have laid the corresponding economic system foundation and ideological basis for the development of democratic politics. Secondly, democratic politics and its external social culture interact and play a role in laying the ideological and cultural foundation for the development of democratic politics. The construction of political culture is an indispensable condition for the construction of democratic politics. It is invisible force to promote the development of democratic politics. At the same time, the development of democratic politics can promote the connotation and value of new social civilization. Finally, there is an ecological relationship of inclusion, mutual dependence and promotion between democratic political construction and social construction. On the one hand, the development of democratic politics can promote social development to be more stable and harmonious; on the other hand, harmonious social construction creates a superior environment for the development of democratic politics. In short, as a part of the overall development of society, the development of democratic politics must continue to deepen with the development of the economy and society, and adapt to the development and changes of the social environment.

\section{The AdAPtABILITY OF DEMOCRATIC POLITICAL RUNNING}

There are many lives in nature, and they can adjust their adaptability independently with the changes of spring, summer, autumn and winter. In the view of political ecology theory, as one of the life entity in many forms of political practice, the democratic political system is also an organic composition with ecological characteristics similar to the life system. This life system will also exchange material, energy and information with its environment, relying on its own holistic and systematic response to various external challenges. It would adapt to the environment. Thus, it would achieve stable and sustainable development.

\section{A. Development of an Adaptive External Political Environment for Democratic Political Construction}

The internal system of democratic politics interacts with its external political environment to form a complete political system. However, the external environment of the democratic political system is different in different periods or issues. The internal system of democratic politics and its functions must adapt to the development of its external political environment.

In the view of political ecology theory, the ecological balance is manifested in the structural organic association and interaction among the various subsystems within the political system. With the external environment, it is in a state of equilibrium, stability and openness in the input and output of information and energy. Due to the influence of historical traditions, economic conditions, social conditions, cultural level, lifestyle and values, democratic political construction should gradually evolve in accordance with its own laws and stages. And it reflects specific goals with its own characteristics at different stages of different periods. Then, it would adapt to the external political environment of the national democratic political system. It is mainly manifested in these aspects. First, the nature and development of the internal ecosystem of democratic politics should be consistent with the political system. Second, the construction of democratic politics should adapt to the overall political situation of the country, and resolve the contradictions and conflicts of national politics. Third, the development of democratic politics should be carried out within the scope of the current legal system. Also, it should promote the institutionalization and legalization of democratic political construction. In addition, the 
construction of democratic politics should be in a manner suitable to the particular time. It would present different construction goals and directions at different times and different stages.

\section{B. Changes in the Adaptive Social Environment of Democratic Politics}

In the social-political ecological relationship, the social environment is the ecological source of the operation of the political system. And the social ecological environment is the basis and scope of the political ecology. The political system lies in the social environment. On the one hand, the political system is bound by the social environment. On the other hand, the political system depends on the nourishment of the social environment. Therefore, the construction of democratic politics must achieve good ecological interaction with the development and changes of the social environment. However, the forms of social development and their level of development in different periods are different. The construction of democratic politics should be in a manner suitable to the particular time at different stages and different periods. And it can adapt to the changes of the economy and society at that time. These two concepts achieve good information exchange and transmission. It would promote harmonious and orderly process of democratic political construction.

According to the ecological theory, "there is competition between individuals, populations and environments in the process of evolution of living individuals and populations. What important is interdependence, coexistence and symbiosis. That is the competition. It usually exists under the larger context of broad cooperation. This is complementary for competition and cooperation." [2] Similarly, in the view of political ecology theory, if an institutional system is to maintain dynamic stability and long-term stability, it must have certain flexibility and corresponding inclusiveness. Also, it has adaptability and self-repairing ability. The mutual adaptation and harmony between the democratic political system and social relations is manifested in the information exchange and energy interaction in interdependence.

\section{The Sustainability of Democratic Political DEVELOPMENT}

The concept of "ecological sustainability" was first proposed by ecologists. It believes that sustainable development is to protect and strengthen the production and renewal capabilities of environmental systems, and to seek an optimal ecosystem to support ecological integrity and the realization of human desires. And the survival of human beings can continue. From the perspective of political ecology theory, the development of democratic politics is also characterized by sustainability. Through continuous optimization of the external environment of the democratic political system, the ecological linkage between the internal system and the external environment is promoted. Also, it would promote the resource sharing, balance and coordination of the two systems of politics and society, and the system optimization of the two systems. Then, it would achieve sustainable development.

\section{A. Taking the Systematic Thought as a Guide to Realize the Common Development of All Elements of Democratic Politics}

In the perspective of political ecology theory, the sustainable development of democratic political construction must adhere to the systematic thought as the theoretical guidance. In the process of practice, we must also take into account the coordination and development of the elements of democratic politics and related environmental conditions. Then, it would achieve common sustainable development. We should carry out democratic political construction under the guidance of systemic thought. We must have an overall conception for democratic political construction, and clarify that democratic political construction should be promoted in an orderly manner. According to the principle of system theory that the overall function is greater than the integration of element function, only the coordinated, balanced and synchronized development of the elements of democratic politics can fully exert the overall function of the democratic political system. At the same time, the contradiction among these internal elements determines the basic trends and processes of democratic political development. In addition, it is necessary to pay attention to the objective connection between the democratic political system and other related systems. It is impossible to achieve sustainable development by relying on the subjective will of others. On the basis of affirming the subjectivity of human beings, we should realize the harmonious coexistence and common development of the democratic political system and its external environment through the practice of unity of purpose and regularity. The ecosystem consisted of democratic political system and its external environment has relevance, interactivity, dynamic development and other characteristics. It would use systemic ideas to guide the construction of democratic politics. It would promote the ecological balance of the elements of the internal system of democratic politics, optimize the external environment of democratic political construction, and promote the energy exchange and ecological interaction among democratic politics, social systems and natural systems. Thus, it can achieve the sustainable development of democratic politics.

\section{B. Promoting the Coordinated Development of Democratic Politics and the Natural and Social Environment with the Principle of Coordinated Evolution}

From the perspective of political ecology theory, the political system and political life should be placed under broader social and natural background and environment. Politics is based on society, and society is based on nature. Political ideas, political decisions, and political behaviors should be adapted to society and nature. As an ecosystem, the political system is constantly evolving. This evolution is manifested in the process of complexity and orderly improvement in time dimension. The constant change of the political system is caused by two factors. The political system and the social environment constitute a complex 
dynamic structure, and there is the exchange of material, energy and information between the two. At the same time, the political system achieves a stable and orderly structure and realizes the self-control and evolution of the system through the interaction of its internal components. The democratic political system is hierarchical and systemic entity composed of subsystems and their elements. The collaborative evolution is realized in the interaction and communication with the external environment, which is characterized by conflict and cooperation among its internal components. The construction of democratic politics must adhere to the principle of coordinated evolution to promote the coordinated development of political, natural and social systems.

\section{Adhering to the Unity of Balance and Imbalance to Maintain the Dynamic Development of Democratic Political Construction}

"For any ecosystem, the balance and imbalance are both dualistic. It is bad for the system. And it is conducive to the development of the system." [1] The life world pursues equilibrium and symmetry. For example, the ecological chain follows the principle of balance. It is the mechanism of balance and conservation that makes life endless. The pursuit of balance and order in human society is even more persevering. The ecological philosopher Hans Sachsse said: "A certain form of organization is likely to be the best. However, we are still looking for it. And various forms are currently continuing to fight with each other. Everything is flowing and changing. In any system, it is not a state, but a process, an open system, and fluid balance." [4] The construction of democratic politics is constantly explored and improved on the basis of national conditions. It is a process of dynamic development. With ecological development characteristics, the development of democratic political construction would be sustainable.

\section{CONCLUSION}

The development of democratic politics is a dynamic process. There is close interaction between the internal elements of democratic political construction and the everchanging economic and social environment. Through the analysis of the ecological characteristics of democratic politics, the ecological nature of democratic politics is mainly reflected in the systemic nature of democratic political construction, the adaptability in the development of democratic politics, and the sustainability of democratic political development. As a part of the overall development of society, the development of democratic politics must continue to deepen with the development of the economy and society, and adapt to the development and changes of the social environment. Only by grasping the ecological characteristics of democratic political development, looking for the niche of various elements within the democratic political system, exerting its systemic advantages, and adapting to the complex internal and external environment can we truly realize the sustainable development of democratic politics and exert its political ecological effects.

\section{REFERENCES}

[1] Liu Jingxi. Political ecology—an ecological investigation of political development [M]. Jinan: Shandong University Press, 2007: 182.

[2] She Zhengrong. Ecological wisdom [M]. China Social Sciences Press, 1996: 94.

[3] Liu Jingxi. Social system and its ecological law_-an analysis from an ecological perspective[J]. Journal of Ningbo Party School, 2002(3).

[4] [Germany] Hans Sachsse. Ecological philosophy [M]. Wen Tao, etc. translation, Beijing: Oriental Publishing House, 1991. 